\title{
Isolation of Nucleoli from the Cellular Slime Mold, Dictyostelium discoideum, Strain A-3
}

\author{
Kazuko Kawashima, Masazumi Sameshima* and Mitsuo Izawa \\ Biology Division, National Cancer Center Research Institute, Tsukiji, Chuo-ku, \\ Tokyo 104 and ${ }^{*}$ Genetics Laboratory, Tokyo Metropolitan Isotope Research \\ Institute, Fukazawa, Setagaya-ku, Tokyo 158, Japan
}

\begin{abstract}
Nuceloli were isolated from the cellular slime mold, Dictyostelium discoideum, strain A-3 without treating the cells with detergent. Electron microscopy showed that the nucleoli were clean and free of contamination by other subcellular organelles. The nucleoli were not surrounded with nucleolus-associated chromatin, but were tightly attached to the nuclear envelopes. The nucleoli contained very little DNA $(1.2 \%)$, but contained considerable RNA (16.3\%). Analysis of the protein components on a SDS-polyacrylamide gel showed many protein bands in a range of molecular weight between 10,000 and 50,000 daltons that are related to ribosomal proteins in the cytoplasm. The phosphorylation profile in vitro indicated that most of the nucleolar proteins were labeled to some extent with [ $\left.{ }^{32} \mathrm{P}\right] .\left[5-{ }^{3} \mathrm{H}\right] \mathrm{UTP}$ incorporation into the nucleoli in vitro was inhibited by actinomycin $\mathrm{D}$, but was completely insensitive to $a$-amanitin; thus, the isolated nucleoli were morphologically intact, and were engaged in ribosomal RNA synthesis.
\end{abstract}

The cellular slime mold Dictyostelium discoideum, has been used as a model organism for the investigation of cellular differentiation, because of the unique morphological changes during its life cycle. Maeda et al. (13) reported that the ultrastructure of the nucleolus in this cell changes at the stage of slug formation. Ishida et al. (5) isolated an anucleolate mutant of the cell, and found that it cannot differentiate further than the culmination stage.

We have isolated the nucleoli from Dictyostelium cells and have analyzed their chemical composition and biochemical functions. During the isolation and characterization of chromatin from Dictyostelium cells treated with the detergent Triton X-100, Pederson (16) obtained a fraction containing a nucleolar component, but he did not analyze it further. We were able to isolate nucleoli from Dictyostelium discoideum, strain A-3 without detergent treatment, and have characterized the ultrastructure, chemical composition, and RNA synthesis in the isolated nucleoli.

\section{MATERIALS AND METHODS}

Cell culture. The cellular slime mold, Dictyostelium discoideum, strain A-3, that undergoes axenic growth was used throughout this experiment. Cells were cultivated in HL-5 medium (13) at $22^{\circ} \mathrm{C}$.

Isolation of nucleoli. All procedures were carried out at $4^{\circ} \mathrm{C}$. Vegetative amoebae cells 
(total $2-3 \times 10^{9}$ cells) were washed several times with $1 / 15 \mathrm{M}$ phosphate buffer $(\mathrm{pH} 6.4)$ by brief centrifugation. Cells were allowed to swell in a hypotonic solution $(2 \mathrm{mM} \mathrm{CaCl})$ for $15 \mathrm{~min}$, then were passed through an Emanuel-Chaikoff homogenizer (clearance, $10 \mu$ ) (6) three times. Subsequent steps in isolation procedures always were checked under a light microscope. More than $95 \%$ of the cells were disrupted by this treatment. Nuclei and unbroken cells sedimented by centrifugation at $1,500 \times \mathrm{g}$ for $10 \mathrm{~min}$ were suspended in $0.25 \mathrm{M}$ sucrose and briefly sonicated for $15 \mathrm{sec}$ at $20 \mathrm{KHz}$. Whole cells and part of the nuclei were disrupted by this sonication. The crude nucleoli and nuclei were then centrifuged at $2,500 \times \mathrm{g}$ for $15 \mathrm{~min}$ and resuspended in $0.25 \mathrm{M}$ sucrose solution, after which they were sonicated six times for $20 \mathrm{sec}$ at $10 \mathrm{sec}$ intervals to disrupt all the unbroken nuclear membranes. The pellet obtained by centrifugation of the sonicate at $2,500 \times \mathrm{g}$ for $15 \mathrm{~min}$ was suspended in $20 \mathrm{ml}$ of $0.8 \mathrm{M}$ sucrose solution, then layered on a discontinuous gradient of $2 \mathrm{M}$ and 2.3 $\mathrm{M}$ sucrose (each $10 \mathrm{ml}$ ) after which the suspension was centrifuged at $20,000 \mathrm{rev} / \mathrm{min}$ for $30 \mathrm{~min}$ in a Hitachi RPS-27.2 swinging rotor. The resulting pellet was free from unbroken nuclei and was used as the purified nucleoli for the following experiments. The final yeild of nucleoli was approximately 20 percent.

Electron microscopic observation. Purified nucleoli were suspended in $1 \mathrm{mM} \mathrm{CaCl}$, then fixed with $2 \%$ glutaraldehyde in $0.1 \mathrm{M}$ cacodylate buffer ( $\mathrm{pH}$ 7.0). After one hour they were fixed overnight with $2.5 \%$ osmic acid in buffer, then they were dehydrated in an ethanolpropylene oxide series, after which they were embedded in Epon 812. Specimens were examined with a Hitachi HU-12A electron microscope.

Chemical analysis. DNA, RNA and protein contents were determined by the method reported previously (6).

$R N A$ polymerase assay. Assays for the incorporation of $[5-3 \mathrm{H}] \mathrm{UTP}$ into acid insoluble fractions were carried out with the following reaction mixture: $5 \mu$ mole Tris- $\mathrm{HCl}(\mathrm{pH} 7.9)$; $0.5 \mu$ mole $\mathrm{MgCl}_{2} ; 1 \mu$ mole $\mathrm{KCl} ; 0.6 \mu$ mole 2-mercaptoethanol; $0.18 \mu$ mole each ATP, CTP and GTP; and $0.1 \mu \mathrm{Ci}$ [5-3 $\mathrm{H}] \mathrm{UTP}$ in $0.1 \mathrm{ml}$. The reaction was stopped by the addition of cold $10 \%$ trichloroacetic acid containing $40 \mathrm{mM}$ sodium pyrophosphate after incubation for $20 \mathrm{~min}$ at $28^{\circ} \mathrm{C}$. The precipitate was collected on Whatman GF/C filter discs. Radioactivity was determined as described previously (9).

Phosphorylation of nucleolar proteins in vitro and their analysis by sodium dodesyl sulfate $(S D S)$ polyacrylamide gel electrophoresis. Proteins in the purified nucleoli were phosphorylated in vitro with $35 \mu \mathrm{Ci}$ of $\left[\gamma_{-32} \mathrm{P}\right] \mathrm{ATP}$ in a $0.5 \mathrm{ml}$ reaction mixture as reported previously (11); the reaction was stopped by the addition of $10 \%$ SDS at a final concentration $1 \%$ SDS. Protein bands and the distribution of [ $\left.{ }^{32} \mathrm{P}\right]$ radioactivity were analyzed by SDS-polyacrylamide gel electrophoresis as described previously (10).

Chemicals. [5-3 H]UTP, ammonium salt $(10-14 \mathrm{Ci} / \mathrm{mmole})$ and $\left[\gamma^{-32} \mathrm{P}\right] \mathrm{ATP}$, ammonium salt (15-17 Ci/mmole) were obtained from the Radiochemical Centre, Amersham. Actinomycin D was purchased from Calbiochem, Los Angeles; $\alpha$-amanitin, ATP, CTP and GTP were products of Boehringer-Mannheim, Mannheim.

\section{RESULTS AND DISCUSSION}

Isolation of the nucleoli and their ultrastructure. Pederson (16) recently reported the isolation of chromatin from slime mold cells treated with the detergent Triton X100 that disrupts the cell membrane. He also briefly described a fraction that contained nucleolar components. Because detergent may change some biological properties of the nucleoli, we decided to isolate nucleoli without it. Cells were first 
homogenized in an Emanuel-Chaikoff homogenizer after allowing them to swell in a hypotonic solution. Nuclei and unbroken cells that sedimented underwent ultrasonic vibration. The sonication procedure was essential to disrupt the cellular and nuclear membranes completely, because the remaining unbroken cells could not be separated from the nuclei and nucleoli by subsequent density gradient centrifugation in a discontinuous hypertonic sucrose solution.

An electron micrograph of the isolated nucleoli is shown in Fig. 1. It indicates that the prepared nucleoli were clean and essentially free from contamination by other subcellular components. Our isolated nucleoli were indistinguishable from those in intact cells (12). This differs from the fraction containing nucleolar components reported by Pederson (16); it included both nucleoli attached to fibrous fragments and other constituents.

There were granular and fibrous portions, along with a few vacuoles inside our nucleoli. Granular components, distributed densely throughout the nucleoli, had a diameter of $150-200 \dot{A}$ (13). This is similar to the size of granular components in the nucleoli of other eukaryotes (14). The nucleoli of this organism were located along periphery of the nucleus, and were closely associated with the nuclear envelopes (12); fragments of the nuclear envelope were clearly attached to isolated nucleoli (Fig. 1). Nucleolus-associated chromatin, which is commonly found in the periphery of nucleoli of mammalian cells (13) was not seen in these cells (Fig. 1). These characteristics of the isolated nucleoli coincided with the electron microscopic observations of isolated nucleoli from another slime mold, Physarum polycephalum. The rRNA gene

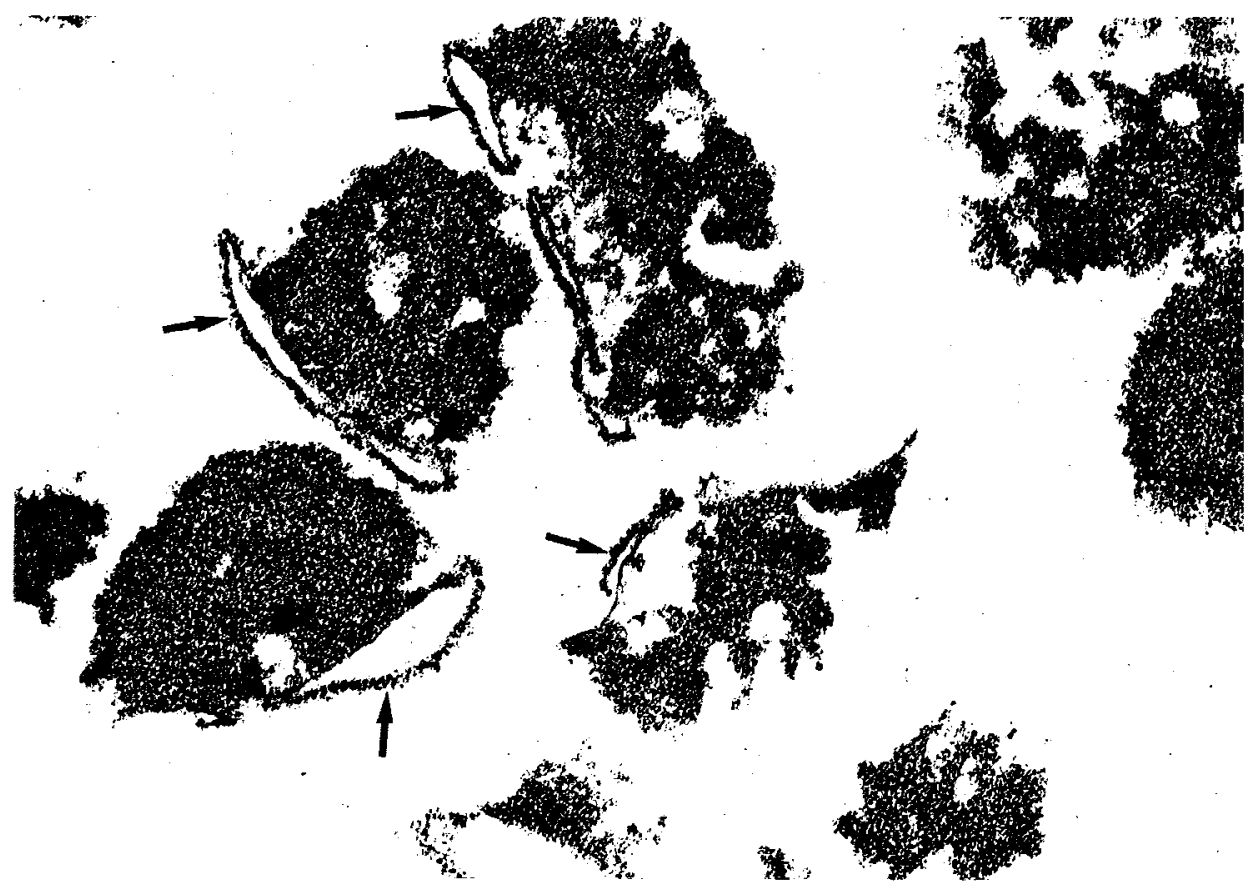

Fig. 1. Electron micrograph of isolated nucleoli from the cellular slime mold, Dictyostelium discoideum, strain A-3 cells. Procedures for the isolation of nucleoli and their electron microscopic observation are described in Materials and Methods. Arrows indicate a region of the nuclear envelope closely associated with the nucleoli. $\times 44,000$ 
has been found only in the nucleoli of this organism (22). Stumpf et al. (18) has reported that Dictyostelium rRNA genes are not contained in the extranucleolar chromosomes; they exist as discrete and free molecules.

Chemical composition of the isolated nucleoli. The nucleoli isolated from the cellular slime mold without the detergent for cell membrane disruption are clean enough to use for biochemical analysis. Their chemical composition was analysed for DNA, RNA and protein. The results in Table 1 show that the DNA content was only 1.2 percent of the total material measured. In contrast, RNA accounted for 16 percent of the total. This percentage for DNA is remarkably low compared with the values for nucleoli of other eukaryotic cells [e.g., $8.3 \%$ in rat liver (15) and $9.3 \%$ in mouse ascites tumor cells (6)]. The amount of DNA per cell or nucleus of this organism is known to be only one-hundredth that of mammalian cells $(4,6,19)$. Although the absolute amount of DNA in a nucleolus was not determined, the absolute amount of DNA per nucleolus also must be extremely low. Our results are consistent with the observation that nucleoli have none of the associated chromatin, that is located in the periphery of nucleoli of most eukaryotic cells (2). The relatively large proportion of RNA in the nucleoli may mean that the intranucleolar space is densely filled with granular ribonucleoprotein particles (Fig. 1). The characteristic chemical composition of nucleoli with DNA, RNA and protein ratios of $1: 13.8$ : 68.8 , also is differs distinctly from the chromatin fraction in the same cells, which is reported as $1: 0.3: 2.3(16)$.

Analysis of protein molecules in the nucleoli and their phosphorylation in vitro. We previously reported the localization of a specific phosphooprotein in isolated nucleoli of mouse ascites tumor cells that has a molecular weight of 120,000 daltons $(10,11)$. This phosphoprotein also has been found in nucleoli isolated from normal and regenerating rat liver cells, rat ascites hepatoma (AH-130) cells, and cultured mouse leukemia (L-5178 Y) cells; it seems to be a common protein constituent in the nucleoli (unpublished results).

To determine whether this protein also is present in the nucleoli of a lower eukaryote, the cellular slime mold, its proteins were analyzed by SDS-polyacrylamide gel electrophoresis. Phosphorylation was achieved by the incorporation of a terminal phosphate of $\left[\gamma^{-32}\right.$ P]ATP in vitro (11) before SDS-gel electrophoresis. Experimental results are given in Figs. 2 and 3. Approximately 50 stained reproducible protein bands were observed on the gel; they ranged in weight from 10,000 to 200,000 daltons (Fig. 2a). Many of the protein bands in the range between 10,000 and 50,000 daltons are related to ribosomal proteins, because ribosomal proteins from the cytoplasm of the cells are distributed in this range (8). The protein pattern of the nucleoli is different from that of the chromatin fraction of the same cells (16); the latter had only a few

TABLE 1. CHEMICAL COMPOSITION OF ISOLATED NUCLEOLI FROM THE CELLULAR SLIME MOLD, Dictyostelium discoideum, A-3 STRAIN

\begin{tabular}{cccl}
\multicolumn{2}{c}{ Chemical composition $(\%)^{\mathrm{a}}$} & Ratios: \\
\cline { 1 - 2 } Protein & RNA & DNA & \\
\hline 82.5 & 16.3 & 1.2 & $\begin{array}{l}\text { RNA/DNA }=13.8 \\
\text { protein/RNA }=5.1 \\
\text { protein/DNA }=68.8\end{array}$ \\
\hline
\end{tabular}

a Sums of the protein, RNA and DNA contents are $100 \%$. Data are averages of two experiments. 


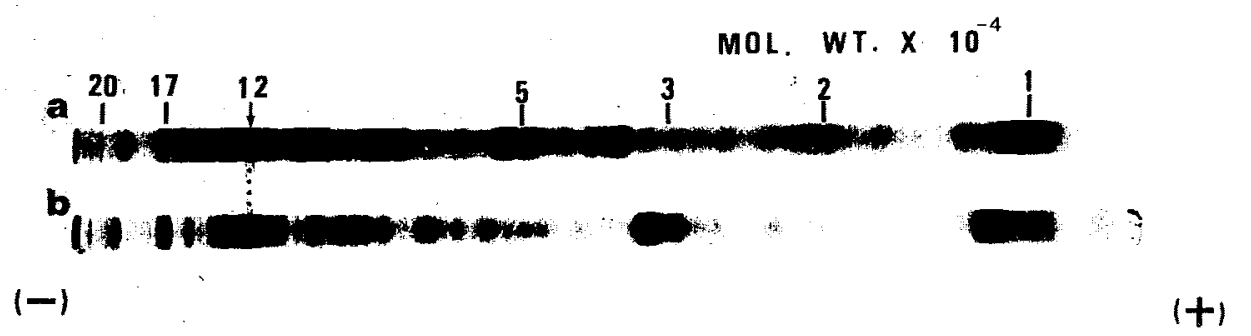

Fig. 2. SDS-polyacrylamide gel electrophotogram of nucleolar proteins in the cellular slime mold and in mouse ascites tumor cells. Sixty $\mu \mathrm{g}$ of proteins from isolated nucleoli of both cells were analyzed by gel electrophoresis as described previously (10). a) Nucleolar proteins of cellular slime mold cells. b) Nucleolar proteins of mouse ascites tumor cells. The arrow indicates a protein band with the same mobility as the nucleolus-specific phosphoprotein (M.W. 120,000).

heavily stained bands in the same region.

Although there was a protein band in the nucleoli of the slime mold that had the same mobility on the gel as the nucleolus-specific phosphoprotein (molecular weight, $120,000)$ presented in mouse ascites tumor cells, the content of this protein in the slime mold was not as high as in the nucleoli of the mouse tumor cells (Fig. 2b). Fig. 2a also shows many heavily stained protein bands with molecular weights ranging from 30,000 to 170,000 daltons.

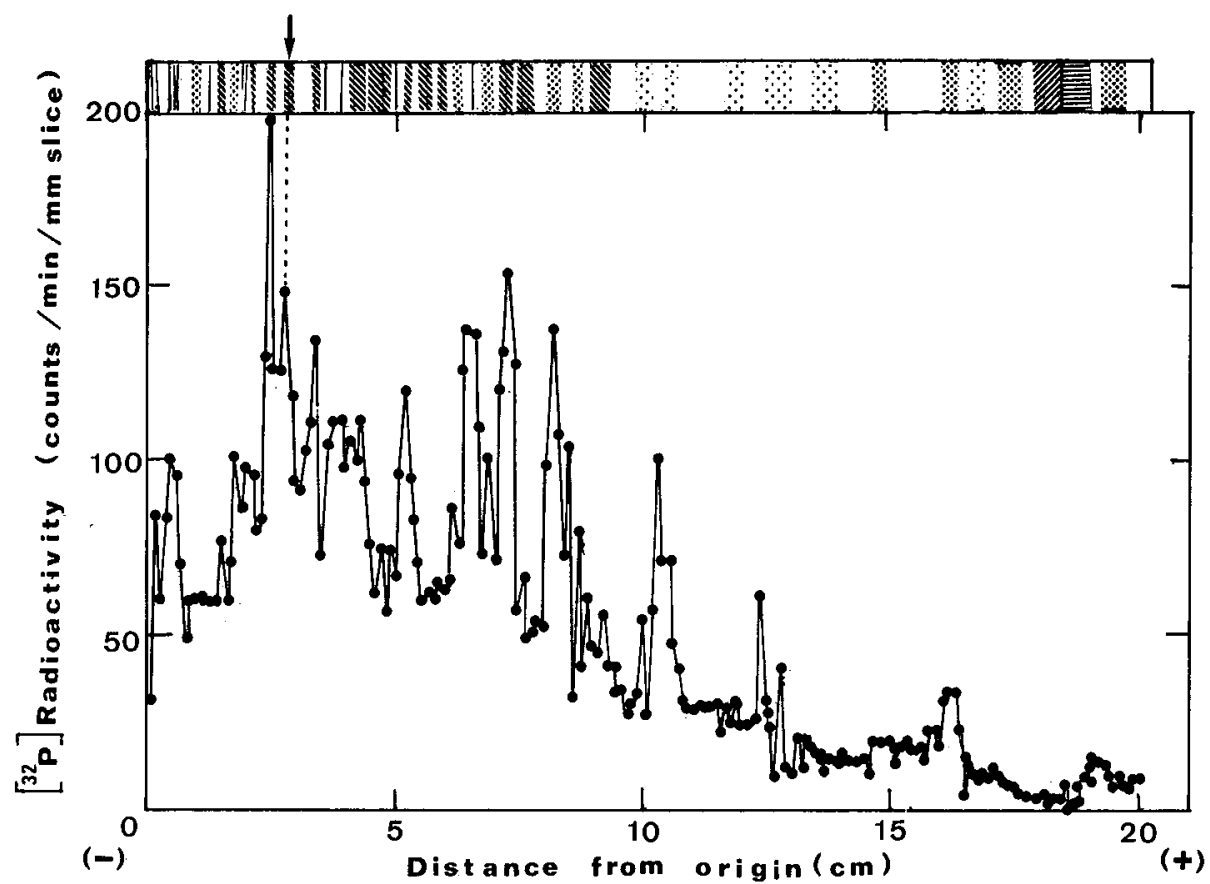

Fig. 3. Distribution of $\left[{ }^{32} \mathrm{P}\right]$ radioactivity in protein bands on the gel of the slime mold nucleoli after phosphorylation of the proteins in vitro. Sixty micrograms of proteins from isolated nucleoli of cellular slime mold cells labeled with [ $\gamma^{32}$ P]ATP for $20 \mathrm{~min}$ were analyzed as described in Materials and Methods. The arrow indicates a protein band corresponding to the nucleolus-specific phosphoprotein. - ; radioactivity, counts $/ \mathrm{min} / \mathrm{mm}$ slice. 
Fig. 3 shows the phosphorylation profile of the nucleolar proteins in vitro. Here again the phosphorylation of a specific protein component $(120,000)$ was not significantly high compared with the other protein bands. Most of the nucleolar proteins, including the histones, were labeled to some extent with $\left[{ }^{32} \mathrm{P}\right]$. Thus the content and phosphorylation activity of the nucleolus-specific protein vary depending on eukaryotic cells studied.

$R N A$ synthesis by the nucleoli. The genes for rRNA are located in the nucleolus, and this organelle is the site of both the transcription of rRNA gene and the assembly of ribosome precursor particles in eukaryotic cells $(1,6,20)$.

To examine the biological function of the isolated nucleoli, we studied RNA synthesis in vitro. $\left[5^{3} \mathrm{H}\right] \mathrm{UTP}$ incorporation into the nucleoli continued for at least $30 \mathrm{~min}$ (Fig. 4), but an addition of exogeneous calf thumus native DNA $(10 \mu \mathrm{g} / 0.1 \mathrm{ml}$ reaction mixture) did not stimulate the incorporation further. This shows that endogeneous DNA in the nucleoli, which was only $0.23 \mu \mathrm{g} / 0.1 \mathrm{ml}$ of the reaction mixture, effective as a template for RNA synthesis in vitro. The requirements for divalent cations, other nucleoside triphosphates, and sulf hydryl groups for incorporation were similar to those found with the nucleoli of other eukaryotic cells (Table 2) (17). The optimum concentration of $\mathrm{KCl}$ was approximately $0.2 \mathrm{M}$ which agrees with the values for the isolated nuclei of slime mold cells (7).

Since it has been reported $(7,21)$ that the RNA polymerase activity in the nuclei of cells engaged in messenger type RNA synthesis is sensitive to both $a$-amanitin and actinomycin $\mathrm{D}$ in the presence of $0.2 \mathrm{M} \mathrm{KCl}$, and that the polymerase for ribosomal

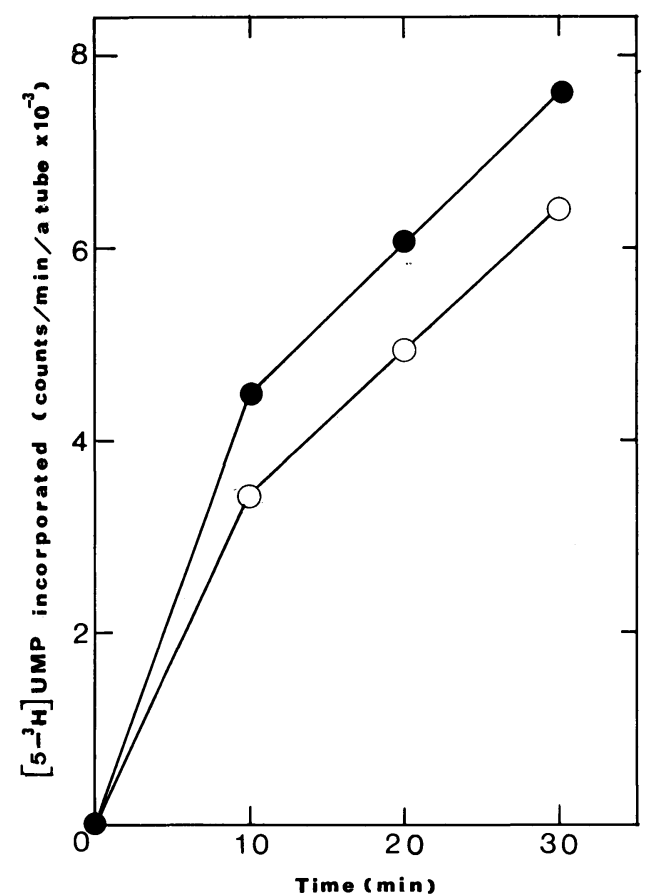

Fig. 4. Time course of $\left[5-{ }^{3} \mathrm{H}\right] \mathrm{UTP}$ incorporation into isolated nucleoli of slime mold cells in vitro. RNA polymerase activity in the nucleoli of the slime mold cells was assayed as described in Materials and Methods. - RNA polymerase activity with the endogeneous template only $(0.23 \mu \mathrm{g}$ DNA/0.1 $\mathrm{ml}$ reaction mixture); $\bigcirc-\bigcirc$, activity with exogeneous calf thymus native DNA $(10 \mu \mathrm{g} / 0.1 \mathrm{ml})$. 
TABLE 2. REQUIREMENTS FOR THE INCORPORATION REACTION OF $\left[5-{ }^{3} \mathrm{H}\right] \mathrm{UTP}$ INTO THE NUCLEOLI in vitro

\begin{tabular}{|c|c|c|}
\hline$\underset{\text { mixture }^{\mathrm{I}}}{\text { Incubation }}$ & $\begin{array}{c}\left.\text { [5- }{ }^{3} \mathrm{H}\right] \mathrm{UMP} \text { incorporated } \\
\text { (counts/min/a tube) }\end{array}$ & $\%$ of control \\
\hline Control & 4,255 & 100 \\
\hline -ATP, CTP and GTP & 298 & 7 \\
\hline$-\mathrm{Mg}^{+2}$ and $\mathrm{Mn}^{+2}$ & 0 & 0 \\
\hline$+10 \mathrm{mM}$ N-ethylmaleimide & 367 & 9 \\
\hline
\end{tabular}

a Incorporation of $\left[5-{ }^{3} \mathrm{H}\right] \mathrm{UTP}$ into the nucleoli in vitro was carried out for $20 \mathrm{~min}$ at $28^{\circ} \mathrm{C}$. For conditions of the incorporation see the legend to Fig. 4, and Materials and Methods.

RNA synthesis is insensitive to $\alpha$-amanitin, the effect of these reagents on $\left[5-{ }^{3} \mathrm{H}\right] \mathrm{UTP}$ incorporation into the nucleoli in vitro was examined (Table 3). RNA synthesis in the nucleoli was not inhibited by $\alpha$-amanitin even at $10 \mu \mathrm{g} / \mathrm{ml}$, although it was blocked strongly by actinomycin $\mathrm{D}$. Thus, it is certain that the isolated nucleoli are the site of ribosomal RNA synthesis, and there was no detectable contamination by the messenger type RNA synthesizing enzyme. These facts indicate that the nucleoli exists as a free and extrachromosomal form.

We conclude that pure nucleoli can be isolated without contamination due to other subcellular organelles or to chromatin fragments without using a detergent to disrupt the cell membrane. Another interesting point is the association of the isolated nucleoli with invagination of the nuclear membrane (Fig. 1). Cell membranes were disrupted

TABLE 3. EFFECT OF $a$-AMANITIN OR ACTINOMYCIN D ON [5-3H]UTP INCORPORATION INTO THE NUCLEOLI in vitro

\begin{tabular}{|c|c|c|c|}
\hline \multicolumn{2}{|c|}{ Incubation mixture ${ }^{a}$} & \multirow{2}{*}{$\begin{array}{c}{\left[5-{ }^{3} \mathrm{H}\right] \mathrm{UMP}} \\
\text { incorporated } \\
\text { (counts/min/a tube) }\end{array}$} & \multirow[b]{2}{*}{$\%$ of control } \\
\hline $\begin{array}{l}\text { Inhibitors } \\
(\mu \mathrm{g} / \mathrm{ml})\end{array}$ & $\begin{array}{c}\mathrm{KCl} \\
\text { concentration } \\
(\mathrm{mM})\end{array}$ & & \\
\hline \multicolumn{4}{|l|}{ actinomycin D } \\
\hline $\begin{array}{l}0 \\
0.1 \\
1 \\
5 \\
10\end{array}$ & 10 & $\begin{array}{r}177,476 \\
84,061 \\
31,006 \\
21,290 \\
0\end{array}$ & $\begin{array}{r}100 \\
47 \\
17 \\
12 \\
0\end{array}$ \\
\hline \multicolumn{4}{|l|}{$a$-amanitin } \\
\hline $\begin{array}{ll}0 & \text { (control) } \\
1 & \end{array}$ & 10 & $\begin{array}{r}9,517 \\
10,861\end{array}$ & $\begin{array}{l}100 \\
114\end{array}$ \\
\hline $\begin{array}{l}0 \\
1\end{array}$ & 30 & $\begin{array}{l}10,826 \\
11,319\end{array}$ & $\begin{array}{l}100 \\
104\end{array}$ \\
\hline $\begin{array}{l}0 \\
1\end{array}$ (control) & 100 & $\begin{array}{l}17,724 \\
18,120\end{array}$ & $\begin{array}{l}100 \\
102\end{array}$ \\
\hline $\begin{aligned} 0 & \text { (control) } \\
10 & \end{aligned}$ & 100 & $\begin{array}{l}13,333 \\
13,191\end{array}$ & $\begin{array}{r}100 \\
99\end{array}$ \\
\hline $\begin{aligned} 0 & \text { (control) } \\
10 & \end{aligned}$ & 200 & $\begin{array}{l}14,908 \\
14,866\end{array}$ & $\begin{array}{l}100 \\
100\end{array}$ \\
\hline $\begin{aligned} 0 & \text { (control) } \\
10 & \end{aligned}$ & 300 & $\begin{array}{l}12,363 \\
12,981\end{array}$ & $\begin{array}{l}100 \\
105\end{array}$ \\
\hline
\end{tabular}

a Conditions for incorporation are described in Materials and Methods, except for the concentration of $\mathrm{KCl}$, and the presence or absence of inhibitors. 
in earlier studies $(3,7,16)$ with detergents during isolation of the nuclei. The likelihood that this association with the nuclear membrane exists in the cell is increased by the fact that the nucleoli are free of the most likely contaminant, extra-nucleolar chromatin, but the significance of this association is unknown.

These procedures may prove useful for the isolation of nucleoli from cells in different phases of the life cycle. The role of the nucleoli during cell differentiation is still to be determined.

Acknowledgments. We are grateful to Mr. F. Hasegawa, the National Cancer Center Research Institute and to Dr. T. Muroyama, the Tokyo Metropolitan Isotope Research Institute for their cooperation on electron microscopic observations. We also thank Dr. David Schlessinger, Washington University School of Medicine for his critical reading of the manuscript.

\section{REFERENCES}

1. Brown, D. D. and J. B. Gurdon. Absence of ribosomal RNA synthesis in the anucleolate mutant of Xenopus laevis. Proc. Natl. Acad. Sci. U.S.A. 51, 139-146, 1964

2. Busch, H. and K. Smetana. The nucleolus. Academic Press, New York, pp. 59-114, 1970.

3. CocucCI, S. M. and M. Sussman. RNA in cytoplasmic and nuclear fractions of cellular slime mold amebas. J. Cell Biol. 45, 399-407, 1970

4. FirTel, R. A. and K. Kindle. Structural organization of the genome of the cellular slime mold Dictyostelium discoideum. Interspersion of repetitive and single copy DNA sequences. Cell $\mathbf{5}$, 401-411, 1975

5. IsHiDA, S., Y. MAEDA and I. TAKeUCHI. An anucleolate mutant of the cellular slime mold Dictyostelium discoideum. J. General Microbiology 81, 491-499, 1974

6. IzaWA, M. and K. KaWASHima. RNA synthesis in the nucleoli of mouse ascites tumor cells in relation to nucleolar components. Biochim. Biophys. Acta 155, 51-62, 1968

7. JACOBson, A., R. A. FIRTEL and H.F. Lodish. Synthesis of messenger and ribosomal RNA precursors in isolated nuclei of the cellular slime mold Dictyostelium discoideum. J. Mol. Biol. 82, 213-230, 1974

8. Kanda, F., H. OChial and M. IWABUCHI. Molecular weight determinations and stoichiometric measurements of 40-S and 60-S ribosomal proteins of the cellular slime mold Dictoystelium discoideum. Eur. J. Biochem. 44, 469-479, 1974

9. KaWAShima, K., M. Izawa and S. Sato. Studies on the origin of proteins in the nucleoli of mouse ascites tumor cells. A test for protein transfer to the nucleoli. Biochim. Biophys. Acta 232, 192-206, 1971

10. KaWashima, $\mathrm{K}$. and M. Izawa. A nucleolus-specific phosphoprotein in mouse ascites tumor cells. Molecular Biology Reports 3, 113-119, 1976

11. Kawashima, K. and M. Izawa. Phosphorylation of a nucleolus-specific phosphoprotein in vitro. Biochem. Biophys. Res. Commun. 74, 265-272, 1977

12. Loomis, W. F. Dictyostelium discoideum. A Developmental System. Academic Press, New York. pp. 17-27, 1975

13. Maeda, Y. and I. TAKeUCHI. Cell differentiation and fine structures in the development of the cellular slime molds. Development, Growth and Differentiation 11, 232-245, 1969

14. MarinozzI, V. Cytochimie ultrastructurale du nucleole-RNA et proteines intranucleolaires. J. Ultrastruct. Res. 10, 433-456, 1964

15. Muramatsu, M., K. Smetana and H. Busch. Quantitative aspects of isolation of nucleoli of the Walker carcinosarcoma and liver of the rat. Can. Res. 23, 510-518, 1963

16. PeDERSON, T. Isolation and characterization of chromatin from the cellular slime mold, Dictyostelium discoideum. Biochemistry 16, 2771-2777, 1977

17. Ro, T. S. M. MURAmatsu and H. Busch. Labeling of RNA of isolated nuceoli with UTP-[ $\left[{ }^{14} \mathrm{C}\right]$. Biochem. Biophys. Res. Commun. 14, 149-155, 1964 
18. Stumph, W. E., J-R. Wu and J. BonNer. Gene enrichment using antibodies to DNA/RNA hybrids. Purification and mapping of Dictyostelium discoideum rDNA. Biochemistry 17, 57915798, 1978

19. Sussman, R. and E. P. RAYNer. Physical characterization of deoxyribonucleic acids in Dictyostelium discoideum. Archives Biochem. Biophys. 144, 127-137, 1971

20. Warner, J. R. and R. Soeiro. Nascent ribosomes from Hela cells. Proc. Natl. Acad. Sci. U.S.A. 58, 1984-1990, 1967

21. Yagura, T., M. Yanagisawa and M. Iwabuchi. Evidence for two-amantin-resistant RNA polymerases in vegetative amoebae of Dictyostelium discoideum. Biochem. Biophys. Res. Commun. 68, 183-189, 1976

22. Zellweger, A., U. RySER and R. Braun. Ribosomal genes of Physarum: Their isolation and repilcation in the mitotic cycle. J. Mol. Biol. 64, 681-691, 1972.

(Received for publication, July 6, 1979) 